\title{
TEJIDOS Y ENTRETEJIDOS Granada siglo XXI
}

Bernardino Líndez-Vílchez² Universidad de Granada

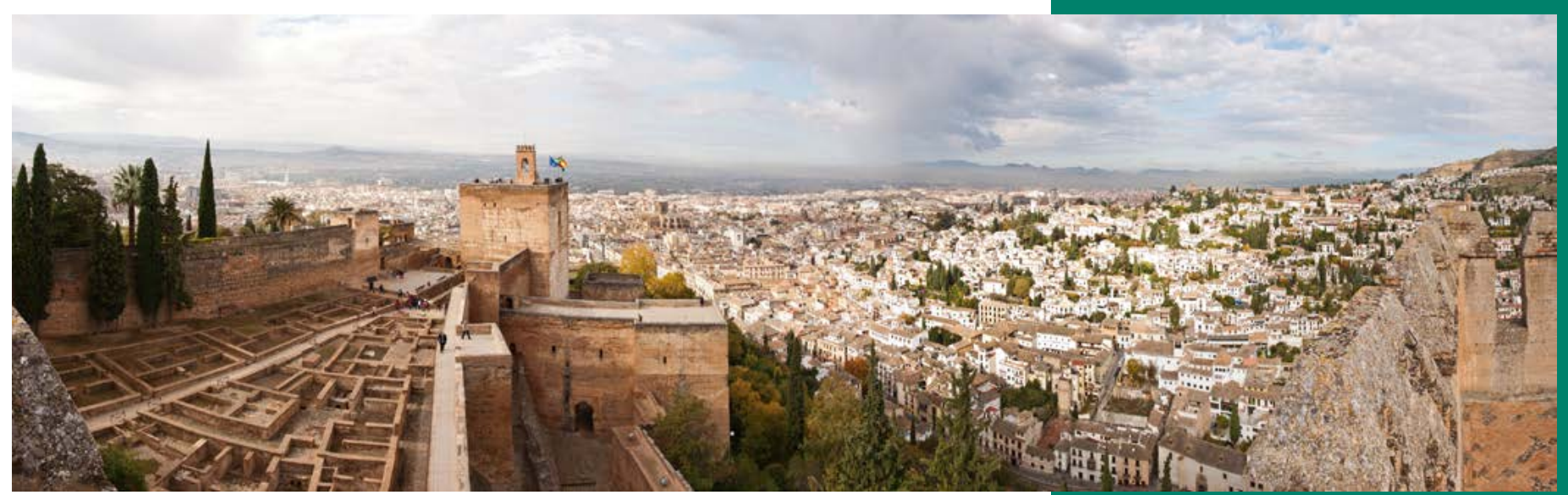

Figura 1. El Albaicín visto desde la Alhambra. Separados por el valle del río Darro, se mantiene entre ambos el estado contemplativo que contribuye a enfatizar el carácter narcisista de la ciudad.

Fuente: Bernardino Líndez-Vílchez. 


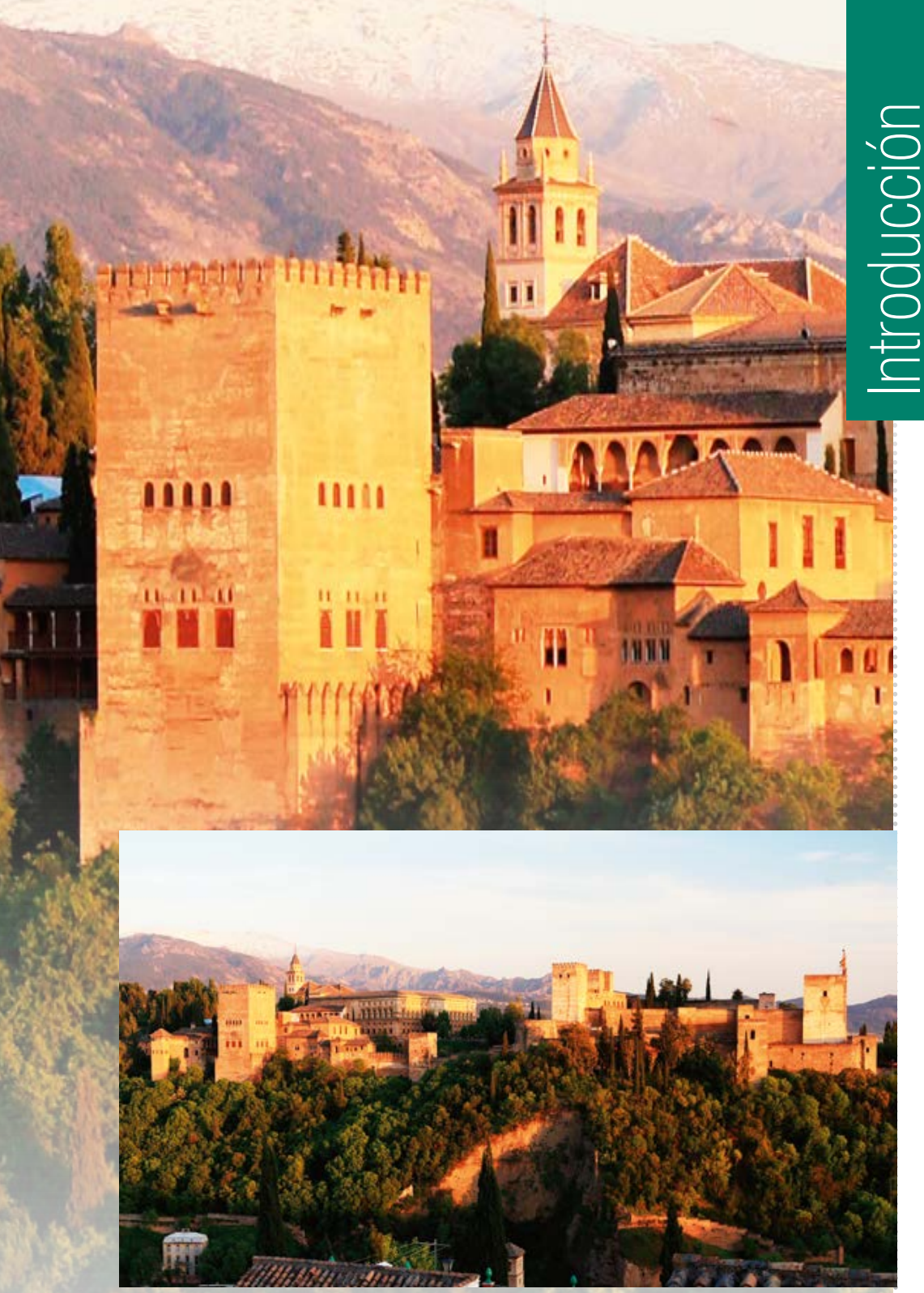

Las ciudades históricas contienen La memoria del espacio y del tiempo, entendido este término en relación al patrimonio cultural, como metáfora de conexión entre pasado y futuro. Es en estas ciudades donde se debe asegurar la continuidad entre pasado y presente para poder construir el futuro ${ }^{3}$

Utilizaremos la idea de paisaje, entendido como la concepción holística de territorio, cultura y vida. El paisaje cultural no tiene nada que ver con los centros históricos, sino con su valor patrimonial. Por el contrario, como dice Koolhaas (2006), la ciudad genérica es la ciudad sin raíces, sin alma, que no precisa su cuidado porque no establece vínculos emocionales y afectivos con sus habitantes.

$\mathrm{Si}$ las ciudades históricas son condensadores de tiempo, dotados de forma, cualquier volumen que entre a formar parte de este sistema cambiará el espacio y por tanto necesitará expresarse como una permanencia. Hemos de aprender de Rafael Moneo, evitando arquitecturas que no sepan leer el lugar ni comunicarse con él, siendo de vital importancia atender a las cualidades de los lugares para evitar fenómenos deslocalizados que generan no-lugares y por tanto la desconexión del hombre con su entorno ${ }^{4}$ :

Figura 2. La Alhambra vista desde el Albaicín. Hemos de imaginarla sin la vegetación que ahora cubre la ladera, destacando la presencia de sus torres cúbicas, rotundas, blancas, armónicamente articuladas en el paisaje a través de lienzos de muralla blancos y en el horizonte la presencia blanca de Sierra Nevada.

Fuente: Bernardino Líndez-Vílchez.

3 Líndez, B y Jiménez, A. (abril, 2017). Granada. El lastre de la historia, pasado y presente. Revista Mouseion Canoas, (26), 12. Recuperado de http://dx.doi.org/10.18316/mouseion. v0i26.3612.

4 Como ejemplo de este proceso de desconexión del hombre con su entorno está el Palacio de Congresos de Oviedo del arquitecto valenciano Santiago Calatrava. Este edificio se convierte en un claro fenómeno deslocalizado en razón de su escala, provocando la ruptura del paisaje urbano y la consecuente desconexión con su entorno. 


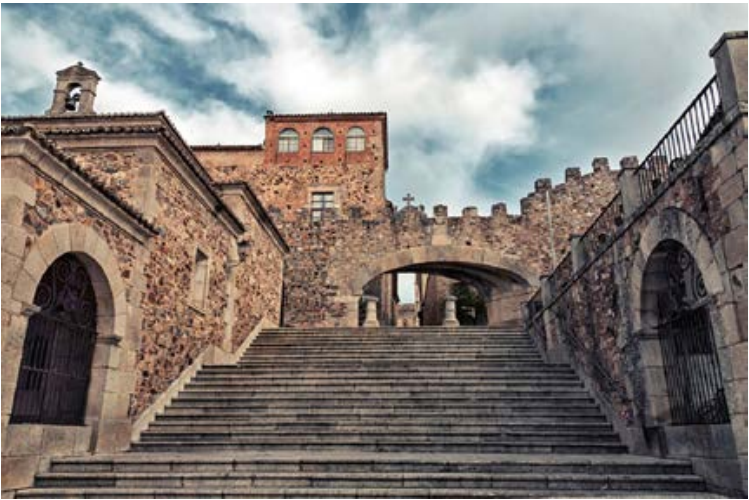

Figura 3. Cáceres, Córdoba y Granada. Tres ciudades de tamaño similar con un rico patrimonio reconocido por la Unesco como Patrimonio de la Humanidad. Cáceres con su centro histórico perfectamente acotado dentro de los límites de la muralla medieval. En Córdoba el centro histórico fluye en torno al eje trazado por el puente romano y la Mezquita-Catedral. El caso de Granada es más complejo, ya que la topografía y las intervenciones urbanísticas recientes han desarticulado sus principales núcleos patrimoniales: Alhambra, Albaicín y el entorno catedralicio.

Fuente: Bernardino Líndez-Vílchez.

Las intervenciones contemporáneas tienen que dar respuesta a la dinámica de cambios que se estén produciendo, facilitando el modelo socio-económico pertinente con una sensibilidad hacia el contexto y las emociones que los habitantes, que sienten suyo el lugar, posean. Así la arquitectura ha de evitar fachadismos e imitaciones pseudo históricas, apostando por respetar la escala y traza del paisaje histórico urbano. El espacio público es crucial en cada uno de los detalles que lo componen además de sus estrategias de uso. La gestión por tanto no solo corresponde al poder político, sino al ciudadano, a través del cual se hace perceptible la conexión secular establecida entre este y el patrimonio de la ciudad (Líndez, 2017, p. 27).

En este contexto habría que preguntarse ¿¿de quién es la ciudad?, de los residentes, de los turistas... y
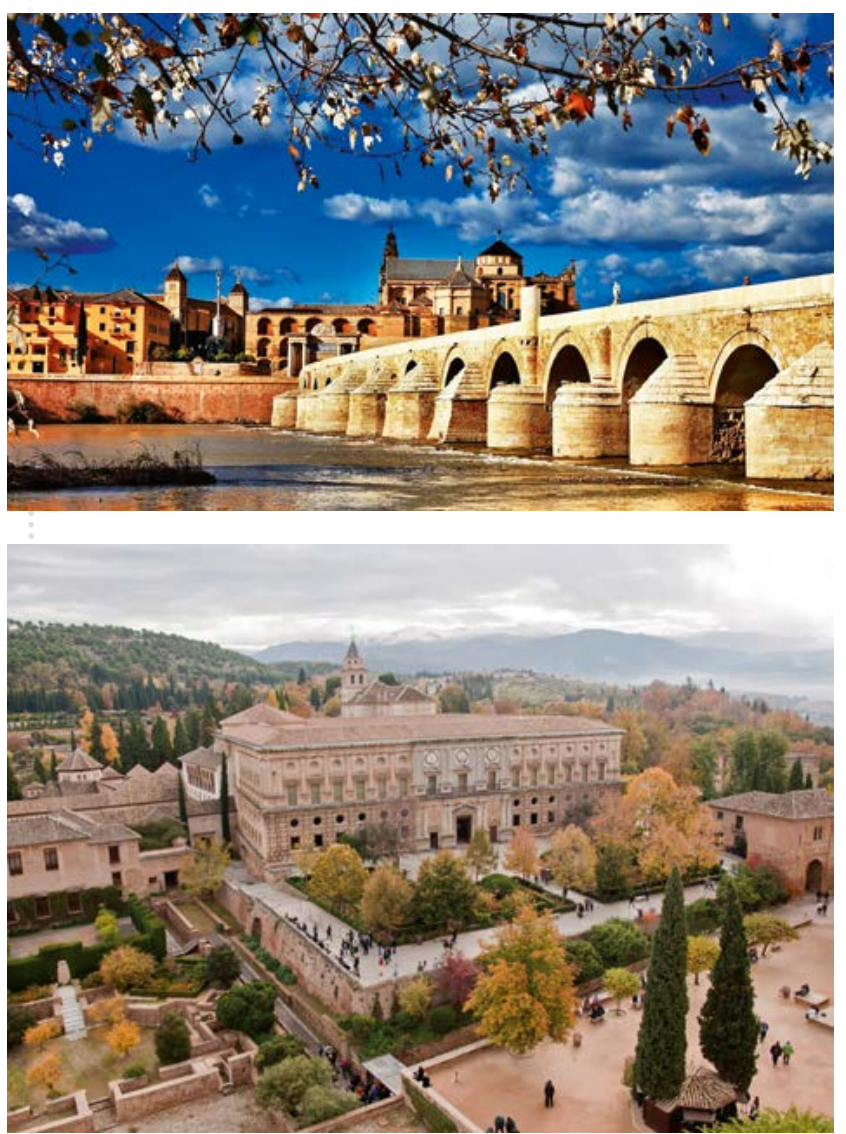

¿por qué aplicamos a nuestras ciudades metrajes matemáticos si lo que hay que observar es su vida?

La belleza y su percepción objetiva es un recurso inagotable y por tanto sostenible. Los valores paisajísticos del Albaicín y de la Alhambra se ofrecen, desde el conocimiento, como un producto cuyo consumo estético exige educar la mirada. El Centro Histórico en el entorno catedralicio es el corazón y el alma de la ciudad que, desde siempre, ha establecido un estrecho vínculo con sus dos principales activos patrimoniales, el Albaicín y la Alhambra. 
Se trata de una fundación romana del siglo I a. C a partir de la característica trama ortogonal de cardo y decumanus. Su población no excedería los 400 habitantes, por lo que en el contexto de la Bética no pasaba de ser una simple aldea.

Con las invasiones bárbaras la ciudad es invisible, por lo que tras la conquista musulmana se funda la ciudad de Madinat Ilvira junto a la sierra de Atarfe, posteriormente destruida en la guerra civil que arrasa el califato entre 1010-1031 y que provoca la fragmentación territorial de Al-Andalus en los reinos de Taifas.

En Granada, la taifa gobernada por la dinastía Zirí se reinstala en el primitivo asentamiento romano, donde ahora se ubica la Alcazaba Qadima o vieja ciudad, en torno a la cual se desarrollan barrios como el del Zenete, Arenal, Axares... cerrados con murallas de manera aditiva, nunca envolvente. Aún se conserva un importante lienzo de tapial con torres salientes, cuadradas y circulares, paralelo a la cuesta de Alhacaba y la práctica totalidad de las infraestructuras: acequias, aljibes, baños. Sin embargo no corrieron la misma suerte las mezquitas que sistemáticamente fueron sustituidas por iglesias. E1 Maristán, incomprensiblemente demolido en el siglo XIX y los palacios, de los que afortunadamente se salva el Palacio de Dar Al Horra, integrado.

La fragmentación territorial de Al Andalus en los reinos de taifas genera constantes litigios fronterizos que acaba debilitándolas, oportunidad que aprovechan los reinos cristianos para ampliar su territorio a costa de estas. Algunas "compran la paz" obligándose a pagar el tributo de las parias y todas tratarán de imitar en lo artístico el esplendor del califato, sirviendo de referencia la Gran Mezquita de Córdoba y la ciudad palatina de Medina Azahara, donde se aquilatan las señas de identidad del arte califal.

Cuando Al Andalus ha visto reducidas sus fronteras a la línea que dibuja el río Tajo, llaman en su ayuda a los ejércitos norteafricanos, primero Almorávides y después Almohades, que centralizan el poder y trasladan la capital a Sevilla, donde llevan a cabo importantes construcciones como la Torre del Oro y la Gran Mezquita Almohade de la que aún se conserva el patio y el alminar: la Giralda, inspirada en el de la Kutuvilla de Marrakesch.

Ante la inevitable pérdida de territorio a favor de los ejércitos cristianos, un caudillo de Arjona llega a la ciudad de Granada en 1238 y se hace con el poder fundando el Sultanato Nazarí, en el que gobernará como Muhammad I. Se somete al tributo de las parias con el que se asegura una paz que se dilata durante algo más de dos siglos. La ciudad se convierte en centro de acogida de musulmanes llegados de territorios limítrofes, experimentando un extraordinario crecimiento económico y urbano. La arquitectura nazarí alcanza un momento de auténtico clasicismo como epílogo de la cultura y el arte andalusí.

El aumento de la población provoca el crecimiento de la ciudad en el llano, que empieza a colonizar la vega con el desarrollo de la Medina y la construcción de la Mezquita Alhama, la Alcaicería, la 


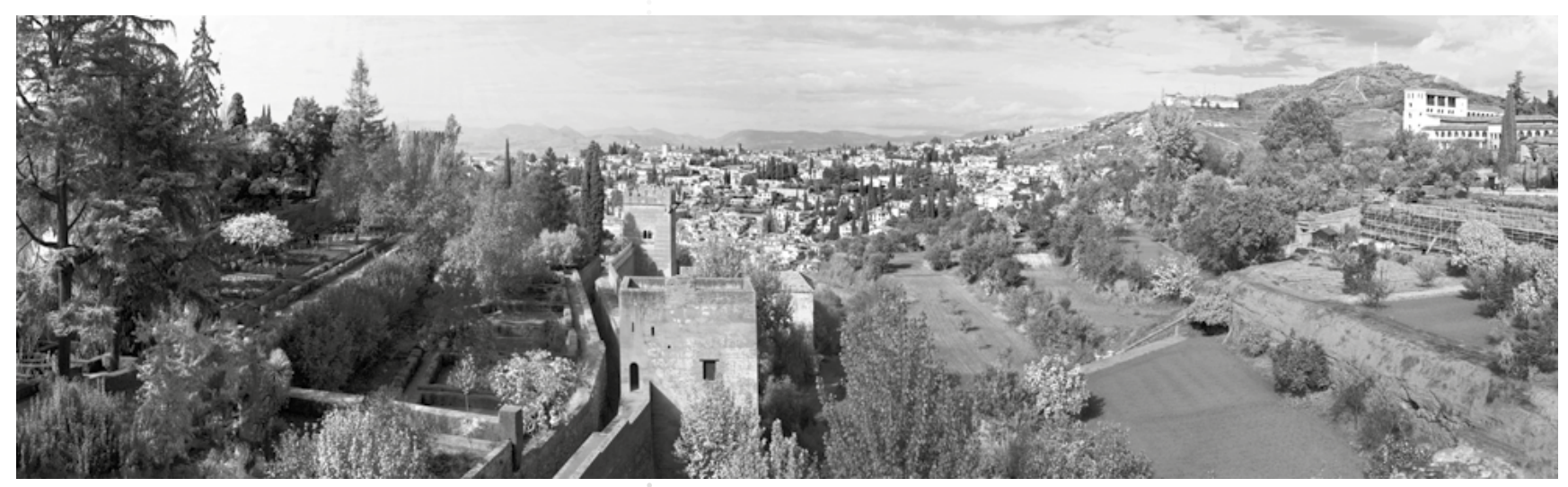

Figura 5. Granada. Arquitectura, Paisaje y Territorio. En primer plano la Alhambra, Ios palacios musulmanes quedan anulados visualmente por las intervenciones cristianas: el Palacio de Carlos V y la Iglesia de Santa María de la Alhambra.

Fuente: Bernardino Líndez-Vílchez.

Alhondiga Yidida. La apertura de puertas en las murallas existentes como Puerta Monaita, la Puerta de Elvira y la construcción de un nuevo lienzo de muralla en el flanco oriental para la ampliación de la vieja ciudad con el barrio del Albaicín o de los Halconeros.

Muhammad I se instala en la vieja ciudad desde la que contempla la colina de la Sabika donde decide construir su ciudad palatina: la Alhambra. La elección del emplazamiento mantiene las constantes aristotélicas y con gran visión de futuro delimita el recinto murado e inicia la construcción de infraestructuras como la Acequia Real, que tiene el punto de captación en el Darro, aguas arriba, a 6 kms de distancia, donde gana la cota suficiente para irrigar incluso los puntos más altos de la Sabika por gravedad.

Los siglos XIII y XIV representan una intensa actividad constructora, llevándose a cabo la casi to- talidad de los Palacios (Partal, Comares y Leones), la Alcazaba y la Medina, que junto al Generalife y las almunias del Cuarto Real de Santo Domingo y el Alcázar Genil, conforman uno de los ejemplos más notables de ordenación territorial y urbana del mundo medieval.

Tras la expulsión del último reducto islámico en suelo europeo y la unificación territorial de la península, los Reyes Católicos son conscientes de haber culminado una empresa en la que no solo se han visto implicados sus ancestros, sino toda la cristiandad. Se apropian de todas las posesiones pertenecientes a la realeza nazarí e inician la sistemática transformación de la ciudad musulmana en ciudad cristiana, interviniendo aquellos edificios que ostentan un importante valor simbólico como las mezquitas, que ceden sus solares para la construcción de iglesias, destacando ahora en el paisaje urbano las torres campanario en la redefinición cristiana de la ciudad. La Alhambra se convierte en casa Real y queda bajo la custodia del conde de Tendilla, como alcaide perpetuo, que 


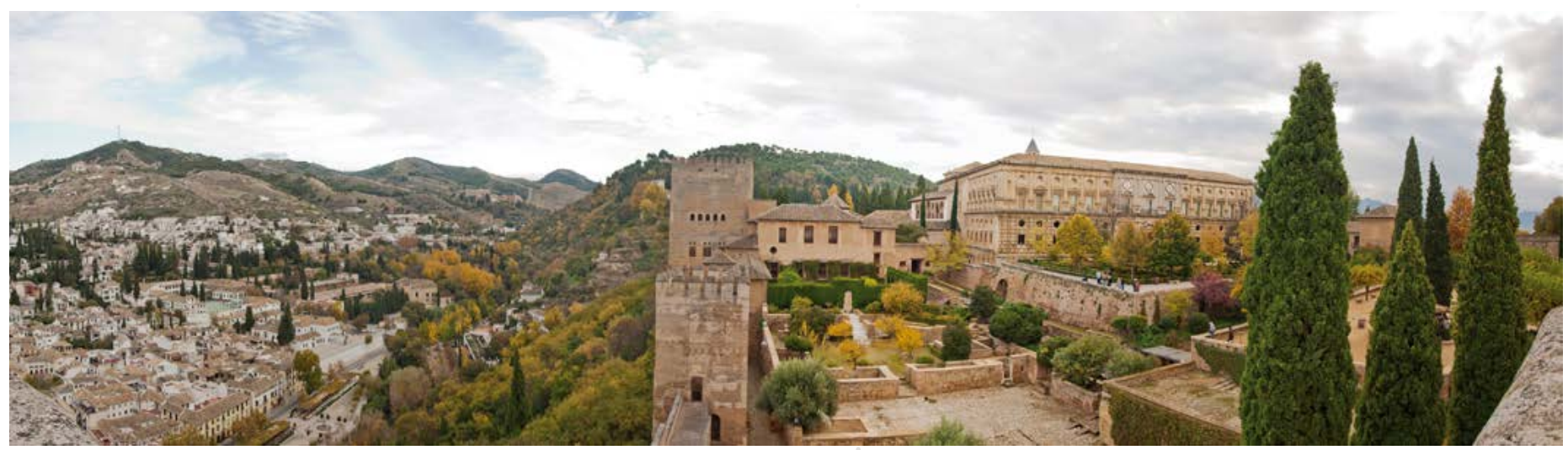

Figura 6. Vista panorámica de la colina de la Sabika, el valle del río Darro y, al fondo, el barrio del Albaicín. La imagen delata la relación entre la ciudad palatina y el Albaicín. El Palacio de Carlos V y la Iglesia de Santa María de la Alhambra se asientan físicamente sobre los principales palacios el primero y sobre la mezquita aljama la

hace hereditario el cargo en su familia y trata el monumento con auténtico mimo.

La ciudad vive una actividad febril en el plano constructivo durante el siglo XVI, auténtico siglo de oro de la arquitectura, con la construcción de un nuevo panteón regio: la Capilla Real y un hospital para dementes: el Hospital Real. Bajo el reinado carolino, el proyecto se completa con la construcción de la Catedral y el Panteón Imperial, la Universidad y el Palacio de Carlos V, cuyo emplazamiento reivindica el único sitio que tiene la condición áulica: la Alhambra. Finalmente, bajoel gobierno de Felipe II se construye la Real Chancillería.

La transición entre el Estado medieval y moderno comporta la pérdida de los privilegios feudales de la nobleza que se ve relegada a nobleza cortesana ${ }^{7}$, sin embargo su contribución al desarrollo urbano y arquitectónico de la ciudad será especialmente

7 La fundación del Estado moderno representa la pérdida de los privilegios medievales para la nobleza a favor de la monarquía que asume el total poder político, militar y administrativo del Estado. La nobleza se verá así relegada a nobleza cortesana, con un papel secundario en la toma de decisiones como simples funcionarios del Estado. segunda, ejerciendo el deseado objetivo de apropiación simbólica del conjunto, que se magnifica en razón de su escala.

Fuente: Bernardino Líndez-Vílchez.

relevante. Doña María de Manrique, esposa del Gran Capitán, completa la cabecera de la iglesia del convento de San Jerónimo como panteón familiar y desarrolla el primer barrio de traza ortogonal de la ciudad: el barrio de la duquesa. Los Granada Venegas, emparentados con la dinastía nazarí construyen la Casa de los Tiros y don Hernando de Zafra, la casa de Castril, actual museo arqueológico.

Si bien la población musulmana, convertida en mudéjar ${ }^{8}$, gozó inicialmente de un estatus similar al anterior a la conquista, la llegada a la ciudad del arzobispo Fray Hernando de Talavera cambia completamente el panorama social y religioso. Desde una posición paternalista y piadosa en su compromiso por la salvación de las almas, lleva a cabo la

8 Son mudéjares los musulmanes que habitan territorio cristiano conservando posesiones, costumbres y religión. 
Figura 7. Vista panorámica del Albaicín desde la Alhambra. Tras la conquista cristiana, se demuelen las mezquitas para edificar sobre el oratorio las iglesias, quedando el patio como plaza. Las torres en su dominio

del paisaje urbano dibujan la imagen de la ciudad cristiana. Tras la expulsión de los moriscos y, sobre todo

a partir del siglo XVIII, se repuebla el barrio edificando

una parte de las manzanas y dejando el resto como huerto o jardín. En estos se construyen cenadores panorámicos con cipreses guiados por estructuras alámbricas que ahora coronan el paisaje urbano. Es la imagen romántica de la ciudad.

Fuente: Bernardino Líndez-Vílchez

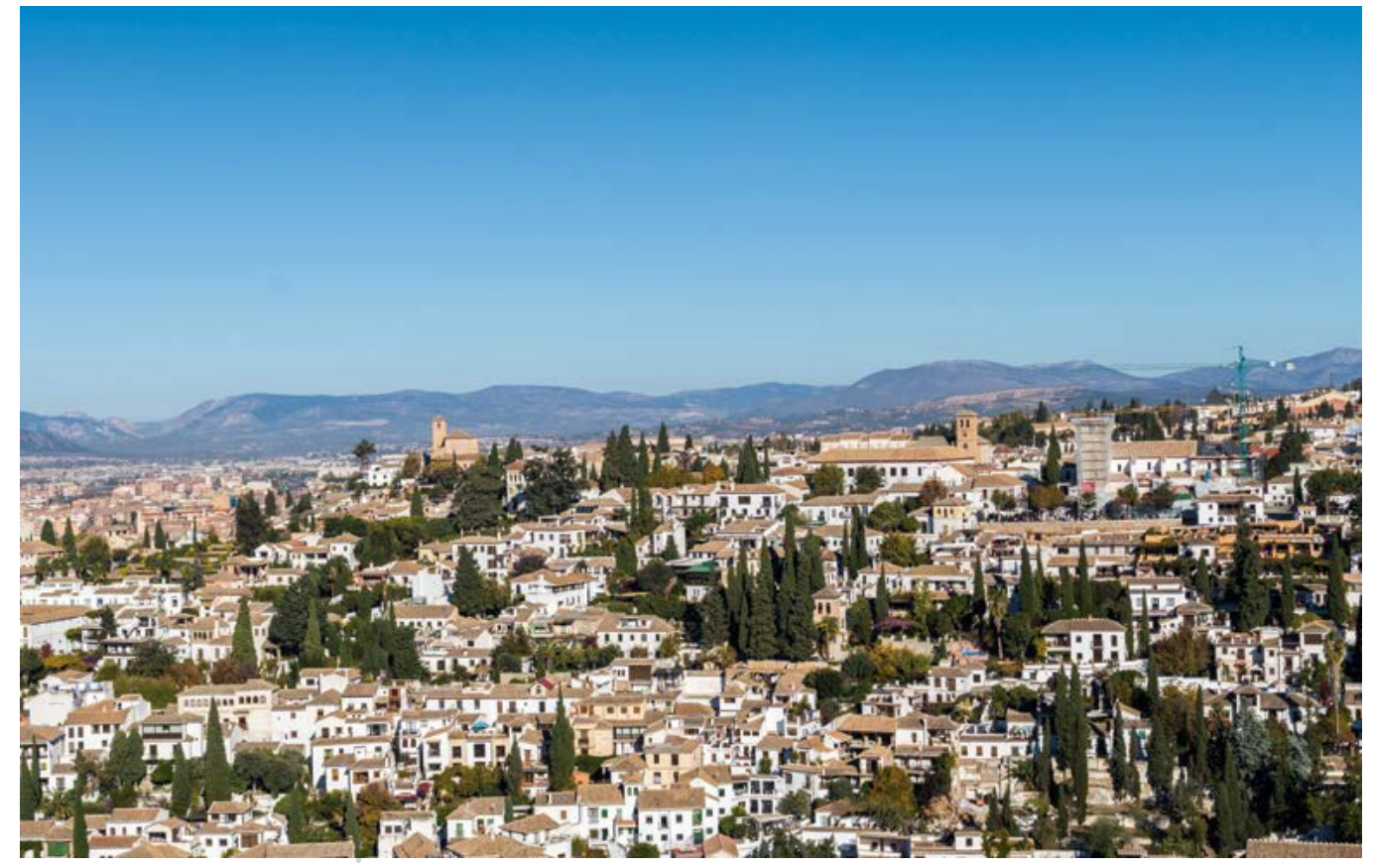

conversión forzosa de los moriscos ${ }^{9}$, articulando un mecanismo de control que tiene en la inquisición ${ }^{10}$ la herramienta de mayor eficacia. La represión que se ejerce sobre los moriscos acaba desencadenando una guerra entre 1568 y 1570 que se resuelve con la expulsión de más de 20.000 ciudadanos, Granada pierde el nervio vital de su economía y el Albaicín pasa de 30.000 a 2.000 habitantes, se inicia una etapa de decadencia que se prolonga hasta el siglo XXI.

Afortunadamente no tuvieron éxito los esfuerzos de Felipe II para repoblar el barrio, por lo que ha llegado a nosotros con el tejido urbano intacto.

9 Son moriscos los musulmanes que habitan territorio cristiano, pero forzados a convertirse al cristianismo y desposeídos de costumbres y parte de sus posesiones al ser obligados a pagar el tributo de la farda.

10 Antiguo tribunal eclesiástico establecido para descubrir y castigar las faltas contra la fe o las doctrinas de la Iglesia.
Los siglos venideros son de nula actividad constructiva, salvo excepciones, hasta la llegada de los viajeros románticos que en la búsqueda del halo orientalizante que aún se respira en la ciudad y sobre todo en la Alhambra, llevan al imaginario colectivo la conciencia patrimonial y la idea de la conservación.

En 1870 la Alhambra es declarada monumento nacional y el Albaicín despierta el interés de la oligarquía granadina que adquiere manzanas completas edificando una parte y destinando el resto del solar a huerto o jardín, pero manteniendo intacta la traza urbana. La imagen romántica se adueña del paisaje sobre todo a partir de la construcción de cenadores panorámicos con estructuras metálicas y la plantación de cipreses guiados por estas que cuando son jóvenes son dóciles, pero que con el tiempo se convierten en los colosos que ahora totalizan el paisaje urbano. 


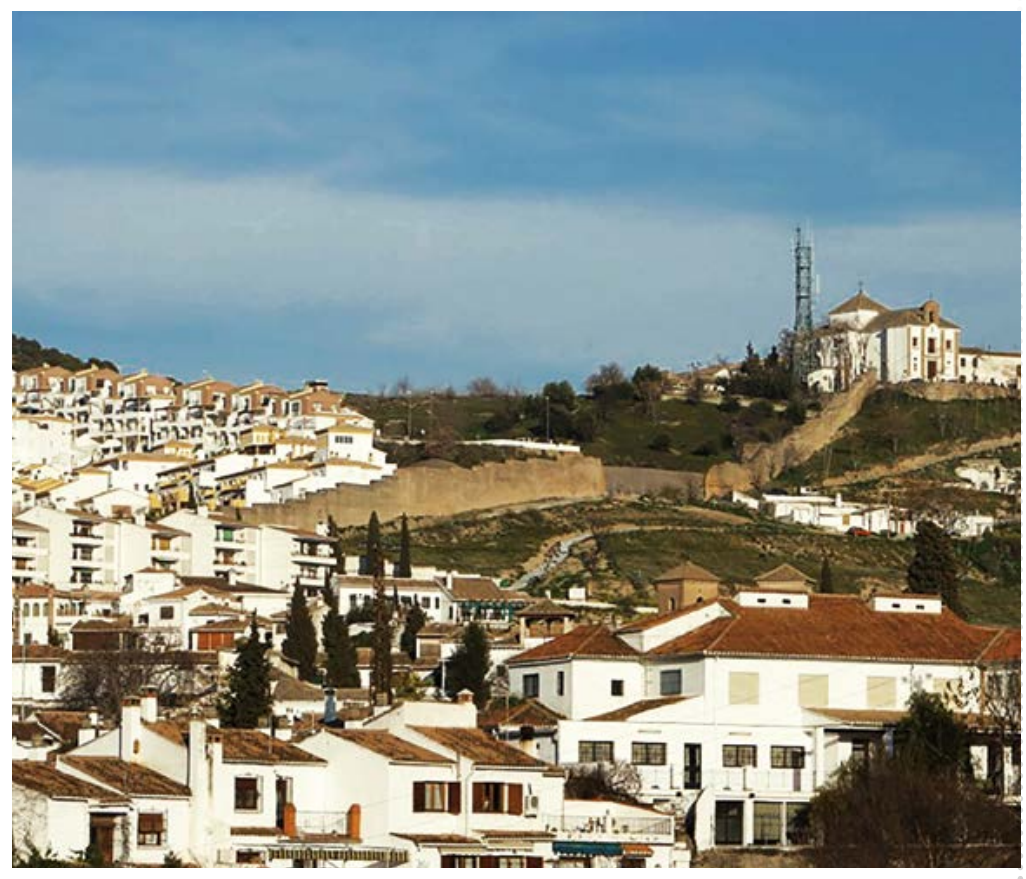

Figura 8. Vista de la muralla nazarí desde el campanario de la iglesia de San Bartolomé. A duras penas se distingue la intervención contemporánea en la muralla y las escaleras de acceso. Por el contrario, es ostensible la colonización ilegal de casas cueva en el vacío acotado por la muralla y sobre todo es especialmente ruidosa la urbanización Cármenes de San Miguel Alto al otro lado.

Fuente: Bernardino Líndez-Vílchez.

En ausencia de una norma urbanística tal cual la concebimos en la actualidad, el Albaicín fue adquiriendo su rostro contemporáneo. Protagonizado por la arquitectura mudéjar fruto del mestizaje de la tradición constructiva musulmana al servicio de proyectos cristianos, tanto en la arquitectura doméstica como en la religiosa, durante los siglos XVI y XVII. Las torres campanario merecen numeral aparte por la fuerza paisajística que tienen en el dominio del horizonte urbano, en constante competencia con la vegetación decimonónica.

La construcción de la grandilocuente Gran Vía a principio del siglo XX secciona el centro histórico desarticulando el tejido urbano e interrumpiendo los flujos humanos entre el este y el oeste, hasta el punto de dejar desiertas las calles Santa Paula y Elvira.

Afortunadamente el proyecto se interrumpe a la altura de la plaza de Colón y lo que inicialmente representa un desatino se convierte en barrera que frena la especulación del barrio histórico, convirtiéndose la vega en blanco del urbanismo depredador de la segunda mitad del siglo XX.

\section{Antonio Jiménez Torrecillas, arquitecto y granadino de adopción}

Conocí a Antonio Jiménez Torrecillas en febrero de 2007, no habíamos hablado nunca a pesar de ser compañeros en la ETS de Arquitectura. Pertenecíamos a departamentos distintos y tampoco ayudaba mucho el hecho de dar clase en unas instalaciones provisionales en las que carecíamos de todo, en tanto se ejecutaba el proyecto de rehabilitación de la escuela actual.

Realizaba yo una visita al Albaicín para estudiantes de La Laguna a la que se incorporó un grupo de la ETSAG, uno de nuestros alumnos me preguntó si visitaríamos la intervención en la muralla nazarí. Fue la primera noticia que tuve del polémico proyecto, nos encaminamos hacia el cerro de San Miguel, recuerdo que era por la tarde, un día luminoso y cálido. La subida fue muy agradable, sobre todo cuando enfilamos la primera de las escaleras. La visión del lienzo de muralla fruto de la intervención no dejó impasible a nadie, no había más que 

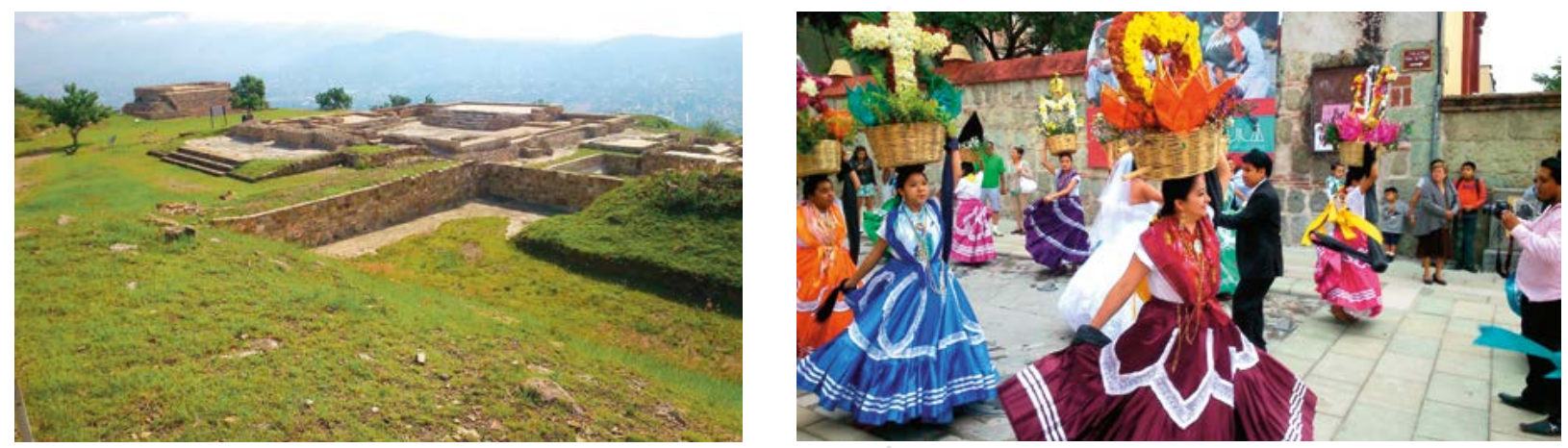

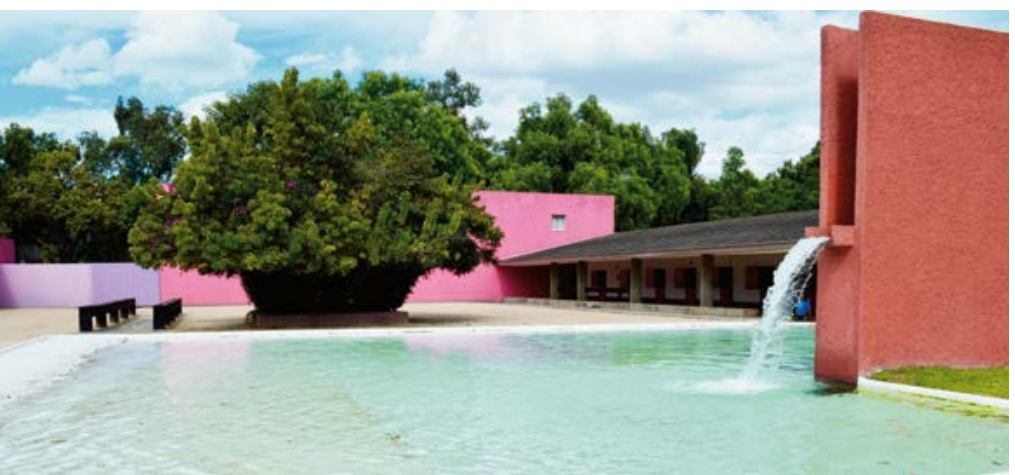

Figura 9. Ruinas prehispánicas de Montealbán, la Calenda ${ }^{3}$ en la ciudad de 0axaca y las cuadras de San Cristóbal, del arquitecto Luis Barragán, en la Ciudad de México

Fuente: Bernardino Líndez-Vílchez.

mirarles el rostro, por lo que se abrió un debate espontáneo.

Dejé exponer todas las opiniones con participación casi unánime. Los detractores eran mayoría, por mi experiencia sabía que tenía que opinar el último para no condicionarles y así lo hice, casi en los mismos términos que lo haré en este texto. Un matrimonio francés filmaba con una cámara de video y aprovechó para grabar mi intervención, después supe que eran íntimos de Antonio, se fueron a su casa y le dejaron ver el video.

3 Las Calendas son parte fundamental de las festividades en Oaxaca. La fiesta es un despliegue de fuerza espiritual, es un singular acontecimiento que potencia la alegría, renueva y fortalece vínculos familiares, comunitarios, personales y dibuja bellísimos paisajes sonoros inundando la calle de color
Antonio se hizo con mi contacto y me llamó agradecido en un momento en que el proyecto despertaba críticas de todo tipo. Yo aproveché la ocasión y le dije que la mejor forma de agradecérmelo sería explicándome el proyecto en el lugar. Me dijo —-Sí, sí, sí, cuando quieras, por supuesto que sí.

-Mañana- le dije. Y quedamos en el bar "los pasteles" en Plaza Larga. Allí tomamos café y hablamos. Se produjo una gran empatía entre ambos. Subimos, él con su vespa desvencijada con la que siempre se desplazaba y yo en mi moto azul. A mitad de camino me preguntó:

— ¿Por dónde quieres que empiece, por arriba o por abajo?

- Me lo he pensado mejor — le contesté- te la voy a enseñar yo a ti.

- Sí, sí, sí- de nuevo con la emoción que transmitía el brillo de su mirada.

Yo sabía lo que Antonio me iba a contar, pero también sabía lo que por pudor se ahorraría y que sería mi aportación. Cuando terminé me abrazó con lágrimas en los ojos y me dijo ¡vamos a emborracharnos! Perdí la cuenta de las cervezas que tomamos 


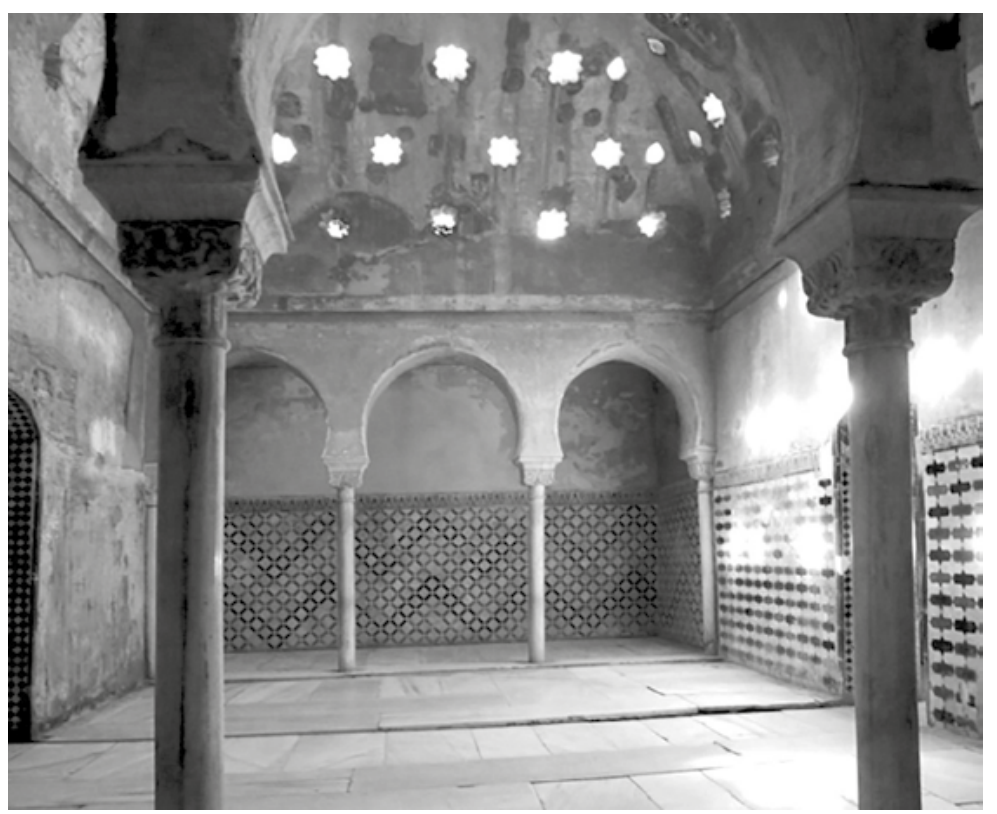

Figura 10. Palacio del Partal y Baños Reales de la Alhambra. El Partal es el primero de los palacios nazaríes en construirse, en él se ensaya con éxito la imagen del muro transparente que se refleja y levita sobre una lámina de agua quieta. La luz perfora las bóvedas del baño y se hace materia, conformando una atmósfera de una gran riqueza sensorial.

Fuente: Bernardino Líndez-Vílchez.

en "la mosca" en el Sacromonte. Fue el inicio de una amistad que ya no se rompería hasta su muerte y que me permitió conocer al profesor, al arquitecto $\mathrm{y}$ al hombre.

He elegido tres de sus obras que en mi opinión reflejan con claridad su manera de entender la arquitectura y que ejemplifican a la perfección el modo en que esta puede tejer (Museo Guerrero) en el Centro Histórico, coser (Intervención en la $\mathrm{Mu}-$ ralla Nazarí) en el borde del Albaicín y establecer puentes entre pasado y presente (Estación Alcázar Genil) en la periferia de la ciudad histórica.
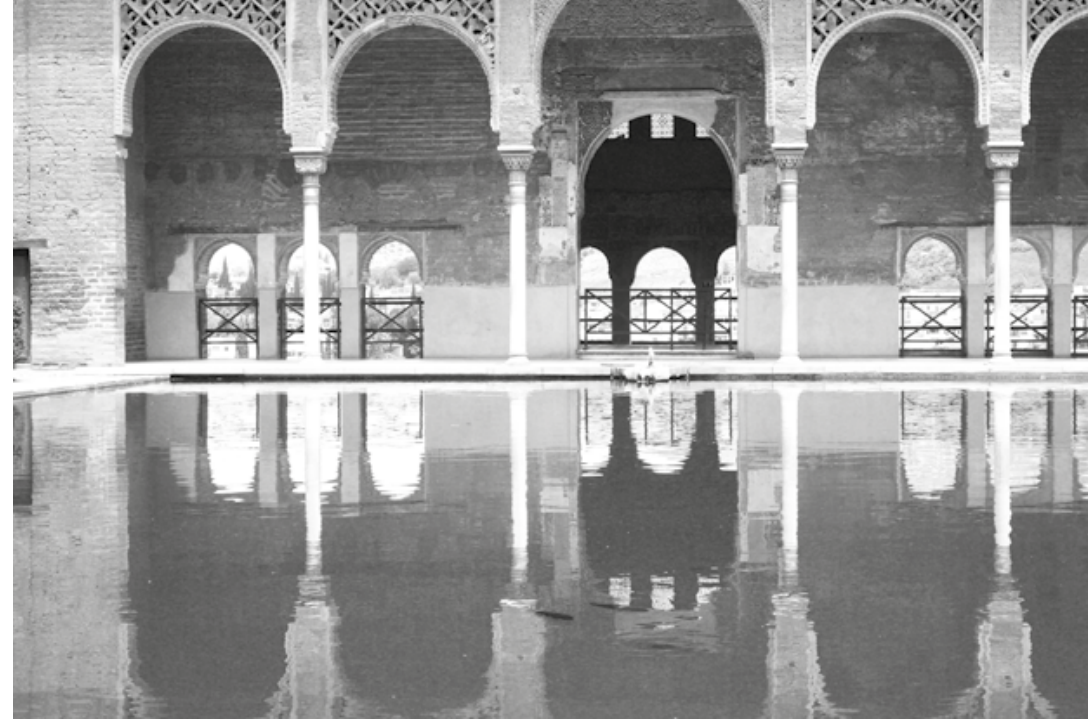

\section{"Vivo en el mundo, pero duermo en Granada"}

Con este manifiesto Antonio proclama la universalidad de su mirada, de su instinto, de sus ambiciones, de sus emociones, de su espíritu, de su amor a la vida y al hombre. Hay en su memoria tres viajes que resultan cruciales en la formación de su pensamiento arquitectónico:

Su viaje a México en la búsqueda del alma de la arquitectura, donde la fuerza y originalidad del arte precolombino, la calidad y el confort de la arquitectura colonial y la vibrante espontaneidad y riqueza de la construcción tradicional se fusionan con el movimiento moderno a partir de la década de los 50. Barragán es su principal exponente, con una obra en la que aflora la paleta de colores indígenas en espacios arropados al abrigo del muro y en los que la luz es protagonista. Ventanas que se abren al cielo y miradas que acarician la naturaleza cargadas de sensualidad, muestran el universo emocional del arquitecto impregnado de recuerdos de su viaje por Europa y los jardines de la Alhambra. 


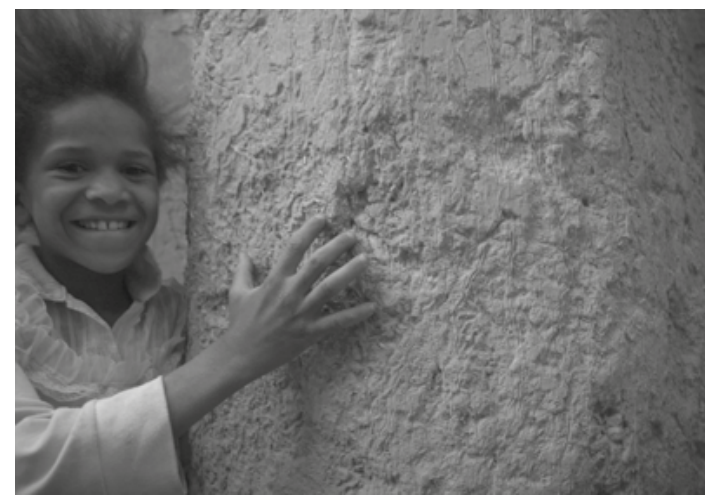

Figura 11. Arquitectura, paisaje y territorio. Tres imágenes de Tamnougalt en el Valle del Draa en tres escalas: interior de una vivienda, horizonte urbano y territorio antropizado. Las tres imágenes muestran la textura amable de la fábrica de tierra en alianza con la luz y el paisaje.

Fuente: Ana Asensio.

Es un viaje de juventud y tras descubrir en auténtico peregrinaje la obra del maestro, hace suyo el consejo dado por éste a un grupo de estudiantes que le visitaban en su casa de Tacubaya: "Ya no se preocupen tanto por ver lo que Barragán hizo, intenten mejor ver lo que Barragán vio". Es un camino de regreso que le conduce a los patios y a las albercas de la Alhambra, láminas de agua quieta convertidas en espejo que hacen de la luz materia con sus reflejos, o el universo estrellado que las luceras del Bañuelo proyectan sobre el vacío de sus salas.

El viaje a través de Marruecos, el Atlas, el Valle del Draa y el Gran Sahara para adentrarse en Mali, lo devolverá a las fuentes primeras de la arquitectura, la arquitectura popular.

Ahora, preferencia general sobre cosas plásticas en el curso de mi vida las he tenido por el primitivo. Un viaje que hice al África es el que más me ha impresionado en mi vida. Vi las construcciones que se llaman Casbahs en el norte del desierto del Sahara, sur de Marruecos; es lo
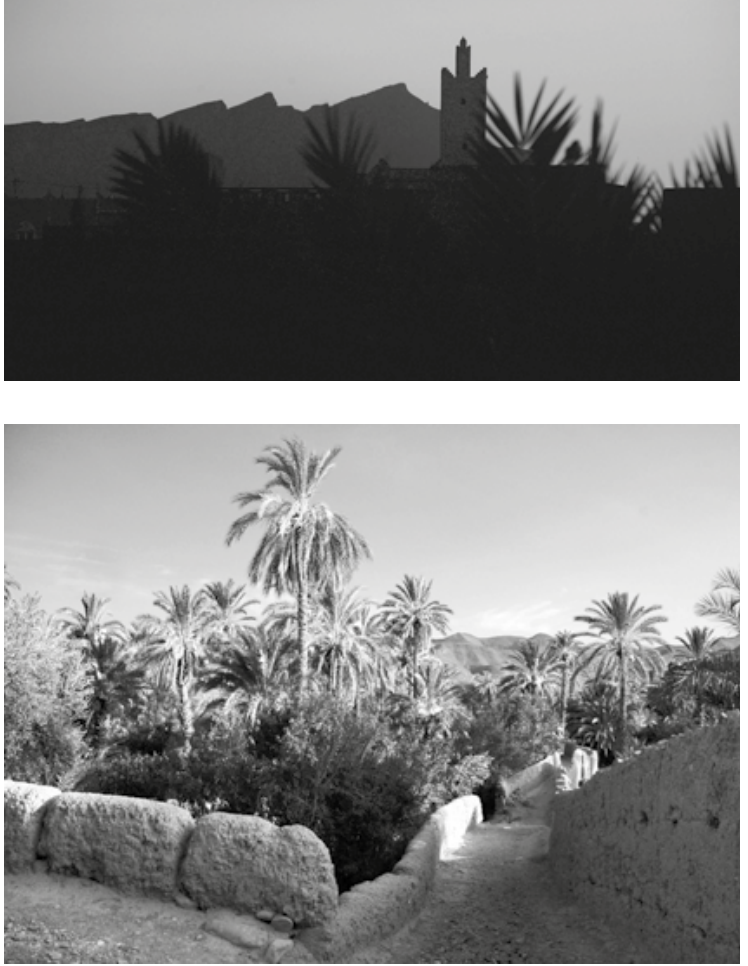

que encontré plásticamente más ligado al paisaje, más ligado a la gente que lo vive, a su ropa, a la atmósfera, inclusive más ligado a sus propias danzas, a su familia. Es decir, encontré ahí la integración perfecta de su religión con todo el ambiente en que viven y las cosas físicas que tocan (Barragán et al, 1991, p.145).

Allí aprendió a hacer de la materia el argumento del proyecto, a desentrañar la universalidad de la materia elemental, de los materiales primeros, las texturas, el color... en ese camino de regreso al origen que representa la arquitectura sin arquitectos.

Entiendo la importancia de este viaje - que desde mi experiencia personal y sin llegar a Mali he podido comprobar, al cruzar el gran Atlas marroquícómo la formación del paisaje empieza con el olor a tierra. La tierra que poco a poco se apodera de los ojos color de tierra, sabor a tierra, la tierra que 


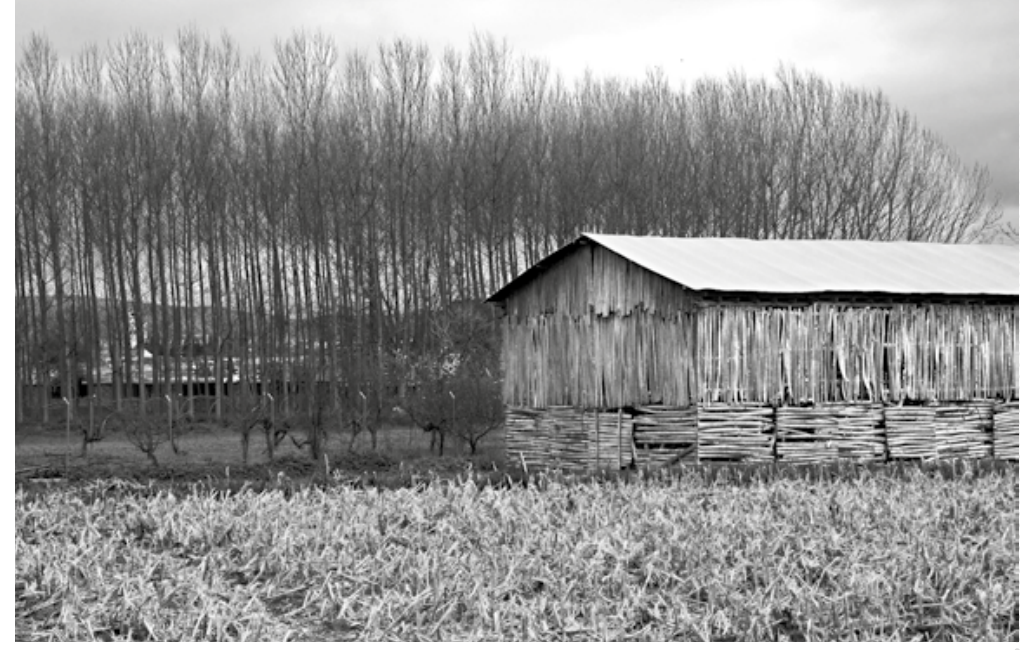

Figura 12. Secadero de tabaco junto a una chopera en la vega granadina. Los secaderos de la vega de Granada adoptan plantas rectangulares con cubiertas sencillas a doble vertiente. La envolvente es siempre un filtro realizado con ladrillo, palos o tablas que transparentan el paisaje. La inspiración vernácula, fuertemente instintiva, da como resultado atmósferas interiores sugerentes gracias al protagonismo de la luz.

Fuente: Bernardino Líndez-Vílchez

empapa el grito y el susurro. La madre tierra que acoge, acuna y cobija. El resultado es un mapa sensorial de formas táctiles, plásticas e irreverentemente amables.

Entre el Atlas y el Antiatlas, nada es lo que era, la mirada no huye, la mirada abraza cada una de las líneas que sentencian la huella del tiempo, el rigor de la historia y la nada. La arena del desierto sube en caravana y coloniza el territorio. Los ojos se entornan y descienden dibujando la textura pétrea del paisaje, como las almas acostumbradas a sufrir la dureza del calor y del viento. El Draa que alimenta se diluye en acequias y canales que la tierra empapa para luego devolverlas a los pozos, donde las mujeres contemplan su rostro cada mañana cuando el sol ni siquiera calienta. Sólo luz, color y magia.

El muro de tierra se eleva tres y cuatro plantas en la formación de las Qasbas. El patio articula el es- pacio arquitectónico, oxigena, ilumina y se abre al cielo recordando de nuevo a Barragán. En él la tierra se deja modelar y expresarse en lenguaje culto, pero de nuevo recuerda su origen y sale del escenario urbano para colonizar el territorio. Se desliza por los caminos y veredas, delimita las fincas productivas y hace visible la presencia del hombre en el proceso de antropización secular del paisaje.

Los viajes a Shanghai y Japón se producen ya en la madurez física e intelectual del arquitecto manteniendo intacta su energía vital, su capacidad perceptiva y su extrema sensibilidad.

El contacto con el jardín chino de Yuyuan en Shanghai donde se muestra la belleza a través de la manipulación de las cosas pequeñas. El uso del muro no con el sentido de abrigo sino para orientar la mirada hacia un inesperado encuentro, para después descubrir que no es la arquitectura lo que pretenden mostrar, sino la lluvia y las piedras junto a las plantas, peces y pájaros.

Descubre la universalidad de la arquitectura japonesa entre la tradición y la modernidad, la desnudez formal y la honestidad material. El manejo de la luz y la penumbra, sin olvidar la referencia constante de la vega granadina con sus secaderos, convertida en auténtico remanso de espiritualidad $\mathrm{y}$ como fuente inagotable de experiencias.

\section{El Centro José Guerrero}

"Recuerdo como Kenneth Frampton, que es quizá el más prestigioso crítico de arquitectura del mundo, 


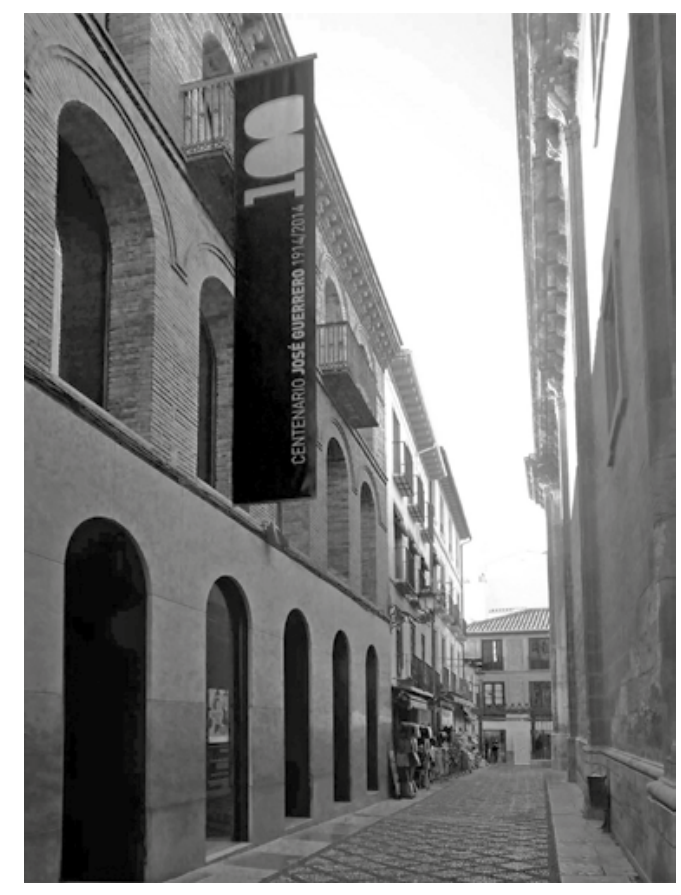

y profesor de la Universidad de Columbia, en Nueva York, se emocionaba cuando le llevé a visitar el Centro José Guerrero de Antonio Jiménez Torrecillas" (Campo, 2005, p. 4).

"La cuidadosa convivencia de piezas iguales, lindantes o pautadas, expresan la emoción de las texturas desde la repetición, matizan transparencias o veladuras e inventan nuevas posibilidades de combinatoria sin recurrir a elementos ajenos" (Hernández, 2015).

"Al arquitecto Antonio Jiménez Torrecillas, fallecido en Granada el 16 de junio a los 52 años, no le tembló el pulso cuando dibujó uno de sus primeros proyectos. Frente a la majestuosa catedral de Granada levantó el Centro José Guerrero, un edificio rompedor, pero sobrio, abstracto y austero que, lejos de enfrentarse a la catedral, se sumaba a ella para recomponer el paisaje de la ciudad. El centro, concluido en el año 2000, es un marco limpio, emblemático
Figura 13. Museo Guerrero, exterior e interior. Tradición y modernidad en perfecta convivencia para un edificio que, sin renunciar al objetivo de servir, nos traslada seducidos por la luz al acto contemplativo frente a la imponente catedral renacentista.

Fuente: Berrnardino Líndez-Vílchez.

y escultórico para la obra del pintor, pero es también, para el visitante, un ascenso en busca de la luz y, por supuesto, un mensaje de futuro: una contribución a la evolución de la ciudad. Como la propia catedral —que añadió la factura renacentista de Diego de Siloé a la obra gótica que le precedió-, las mejores ciudades son las que suman y se transforman con el tiempo, las que se levantan a capas" (Zabalbeascoa, 2015).

Desde siempre la arquitectura contemporánea ha invadido el Centro Histórico. Basta con recorrer Roma para comprobarlo, piazza Navona se construye sobre el estadio de Domiciano, conformando uno de los escenarios barrocos más cualificados de la ciudad. Del mismo modo el excelente palacio Orsini de Baldassarre Peruzzi se levanta sobre el Teatro Romano de Marcelo.

A vista de pájaro, la presencia de la caja blanca de la planta mirador del Centro Guerrero me recuerda a Sant' Ivo alla Sapienza. Construida en el patio del imponente edificio de la Universidad 
realizado por Giacomo della Porta, establece una complicidad lingüística, de escala y de ritmo compositivo muy contenida en su frente principal, sin renunciar al artificio barroco. Superada la cota del edificio renacentista, Borromini desborda fantasía y creatividad a partir del característico juego cóncavo convexo, cuyo paroxismo se hace visible en la linterna subrayando la diferencia con su inmaculado color blanco.

La caja blanca que corona el Centro Guerrero enfrentada a la catedral renacentista establece un diálogo visual en el que cada una de las piezas que conforman ese horizonte urbano reclama con su presencia el fragmento de tiempo con el que se construye la historia. Pasado y presente se renuevan en un ejercicio brillante de arquitectura capaz de tejer y recomponer el paisaje del entorno catedralicio.

La Scala Regia en los Palacios Vaticanos, en su ascenso, construye la perspectiva a partir de la pirámide visual. Allí el engaño barroco se completa con parejas de pórticos de columnas a ambos lados e introduciendo la luz que se filtra a intervalos. En el museo Guerrero, Antonio acentúa el efecto de perspectiva con idéntico artificio en la búsqueda $y$ conquista de la luz, que se muestra esquiva hasta coronar el ascenso. La recompensa es la historia petrificada a través del acto contemplativo.

Se trata de un edificio del siglo XIX situado en la calle Oficios frente a la Lonja y la Capilla Real. La fachada es de mampostería de ladrillo y estructura metálica en el interior articulado en torno a un patio.
La audacia del arquitecto ha estado en saber leer esa doble caja ${ }^{11}$, la de la envolvente y la que conforma el patio inundado de luz, para convertirla en el argumento del proyecto. Mantiene intacta la piel del edificio, actuando sólo en el nivel inferior mediante un aplacado marmóreo que refuerza el ritmo compositivo de las arcadas, ahora mediante el abstracto. La caja hueca del patio, ampliada de escala, perfora el edificio desde arriba y se hermetiza. Se obtiene el espacio museístico adecuado en escala y geometría a la obra del pintor. La galería que resulta entre ambas cajas filtra la luz y el paisaje urbano recomponiendo la irregularidad de la planta.

En esta obra de juventud, Antonio demuestra la madurez de su pensamiento arquitectónico resolviendo magistralmente el programa funcional y constructivo. Manipula el espacio a través de la luz que se hace materia, y sugiere un emocionante recorrido de ascenso impulsado por la perspectiva con la luz como horizonte, para finalmente sumergirnos en la historia ${ }^{12}$.

\section{La muralla nazarí en el Alto Albaicín}

"Con la misma idea de sumar, de respetar, de atender a lo que había y de contribuir a lo que habrá, levantó en 2006 una pieza de land art pensada para

\footnotetext{
11 "La estructura espacial original, que estaba formada por dos cajas, una exterior y otra interior que se convertía en patio, se ha reinterpretado de manera muy ingeniosa" (Campo Baeza, 2006, p. 6)

12 Resulta tentador establecer paralelismos entre el museo Guggenheim de NY que desplaza al visitante al último piso para desde allí iniciar el recorrido de descenso a través de la obra de arte. El Centro Guerrero de AJT nos invita a realizar ese camino de ascenso impulsados por el ejercicio arquitectónico, para después contemplar la obra del artista en el camino de vuelta.
} 


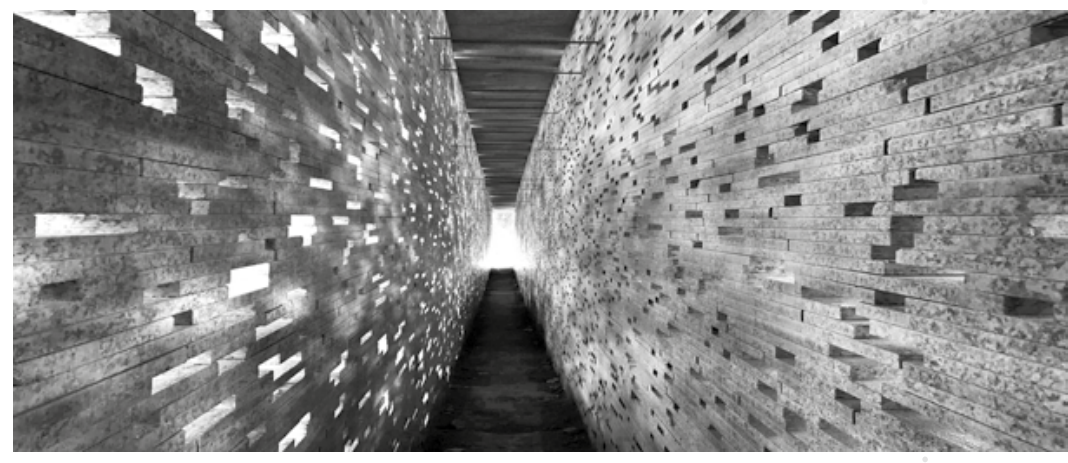

Figura 15. Después de múltiples combinatorias materiales y constructivas, el arquitecto se decide por el granito rosa colocado a hueso, en una insinuación de apilamiento, que libera a intervalos aleatorios pequeños agujeros que filtran el paisaje y la luz, recreando en clave de modernidad, atmósferas recurrentes en las salas de la Alhambra. La sección constructiva evidencia el cuidado respecto con la historia de una intervención reversible que se convierte en una oferta sensorial, como puede verse en la imagen.

Fuente: Bernardino Líndez-Vílchez.

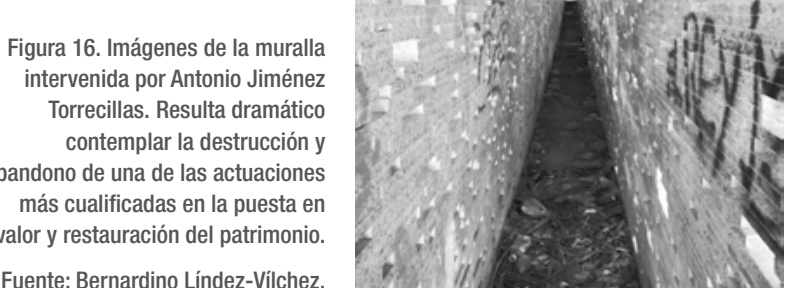

y acotando una parte de territorio llamado a conver-
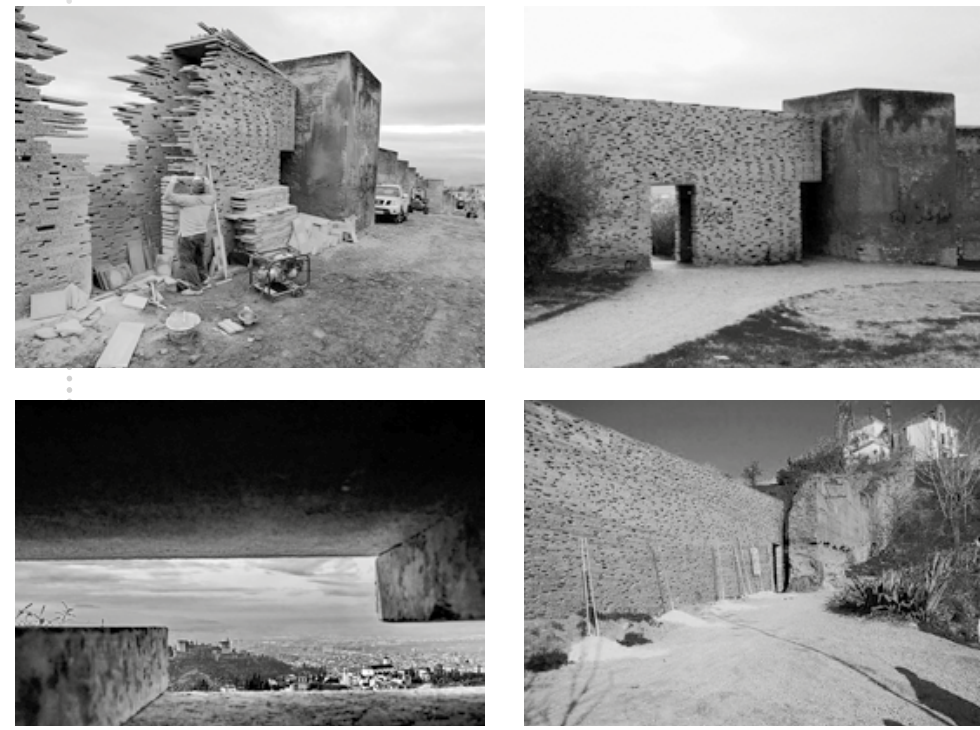
tirse en el barrio del Albaicín o de los Halconeros. Su privilegiada posición paisajística, en la vertiente del Darro frente a la colina de la Alhambra y abierta a la llanura de la vega, hacen de este lugar un auténtico regalo para los ojos. Es también la rótula que articula la ciudad con el territorio y el Sacromonte a través del vacío, de lo tectónico a lo estereotómico (Líndez, 2017, p. 27).

La acumulación de ingentes cantidades de basura, junto a la pérdida de unos 40 metros lineales de la muralla nazarí, habían provocado una fuerte degradación del lugar protegido por el PEPRI de

1990 y declarado Patrimonio de la Humanidad por la Unesco en 1994.

Antonio Jiménez Torrecillas, tras la limpieza del sitio, proyecta la restauración del paisaje a través de un recorrido panorámico. Dos escaleras realizadas con bloques de granito gris oscuro, sentados directamente sobre el terreno y fijados entre sí con resinas conforman el peldañeado que se adapta a la topografía del terreno sin agredirlo. Establece así un sendero de ida y vuelta, desde la calle Carril de San Miguel a la placeta de la Cruz de la Rauda a 
través del vacío acotado por la muralla. Cada peldaño y cada rellano ofrecen un diaporama en el que la mirada deambula desde la vertiente del Darro, pasando por el Generalife y sus huertas, y acariciando la ciudadela de la Alhambra. Del otro lado el Albaicín, la ciudad compacta coronada por cipreses colosales que compiten con las torres de las Iglesias en el dominio del horizonte urbano. Entre el duelo de gigantes se filtra la mirada para perderse en la lejanía de la vega, que se ofrece cada tarde como escenario privilegiado a extraordinarias puestas de sol.

Para la restauración de la muralla se emplea un sólido capaz ${ }^{13}$ desplazado de la alineación de aquella sin llegar a tocarla. Se formaliza el volumen mediante un doble muro construido con placas de granito rosa sentadas a hueso y fijadas con resinas que sugieren un apilamiento. El resultado es un aparejo que libera aleatoriamente huecos a través de los cuales penetra la luz y el paisaje. Ambos lienzos de muro se cobijan y cierran en la parte superior con las mismas placas de granito reforzadas con tirantes metálicos. Entre ambos se libera una galería interior de un metro de ancho que permite el tránsito intramuros.

Es una oferta sensorial capaz de recrear una atmósfera similar a la que se percibe en las principales salas de la Alhambra. Fragmentos del paisaje recortados que inundan la retina, a través de los cuales se filtra la luz dibujando caprichosas geometrías con la sombra, despiertan la fantasía. Es la vuelta al útero materno, en ese camino de regreso al estado

13 Por sólido capaz se entiende la formalización del volumen original. de gracia, como traducción plástica de un ejercicio intelectual profundo, capaz de atrapar a través de la arquitectura el alma de la ciudad.

La actuación a cierta distancia se mimetiza con el entorno. A pesar de todo, se ha intoxicado la opinión pública logrando un fuerte rechazo, que ha provocando una perversa actuación municipal (desde la ignorancia) con la apertura de una puerta. Abandonada a su suerte, colmada de basura y como soporte de grafitis, sigue generando constantes visitas de un público exigente que sabe reconocer el ejercicio de síntesis del arquitecto en la materialización conceptual del proyecto ${ }^{14}$.

\section{La estación Alcázar Genil}

"Diseñando interiores y cuajando intervenciones urbanas, la estación tiende, de nuevo, un puente entre los restos arqueológicos de una alberca almohade del siglo XIII — que debieron esquivar-y la futura movilidad de su ciudad" (Zabalbeascoa, 2015).

El Alcázar Genil es un palacio de recreo, una almunia integrada en un conjunto de huertas productivas en el borde de la vega de Granada junto a la margen izquierda del río Genil. Construido en el siglo XIII bajo el gobierno Almohade de Al-Andalus, fue reformado y enriquecido orna-

14 Esto no ha impedido el reconocimiento como finalista en el IV European Prize for Urban Public Space 2006; Premio FAD Socis Arquinfad 2006; Premio Arquitectura Piedra 2006; seleccionado al Premio Mies Van der Rohe 2007; Premio International Cappochin Biennal Architecture Padua 2007; X Premio Internationale Architectura in Pietra, Verona 2007 y el Premio de Arquitectura Española a la mejor intervención en el Patrimonio Histórico Nacional 2007. 
Figura 17. Foto aérea del río Genil y el Alcázar

Genil. Precede a la fachada la urbanización

Jardín de la Reina, conformada por dos

pastillas cuyos sótanos destruyeron la alberca que sólo se salva en el tramo que atraviesa e camino de ronda ortogonal a estos.

Fuente: Jiménez-Torrecillas et al.

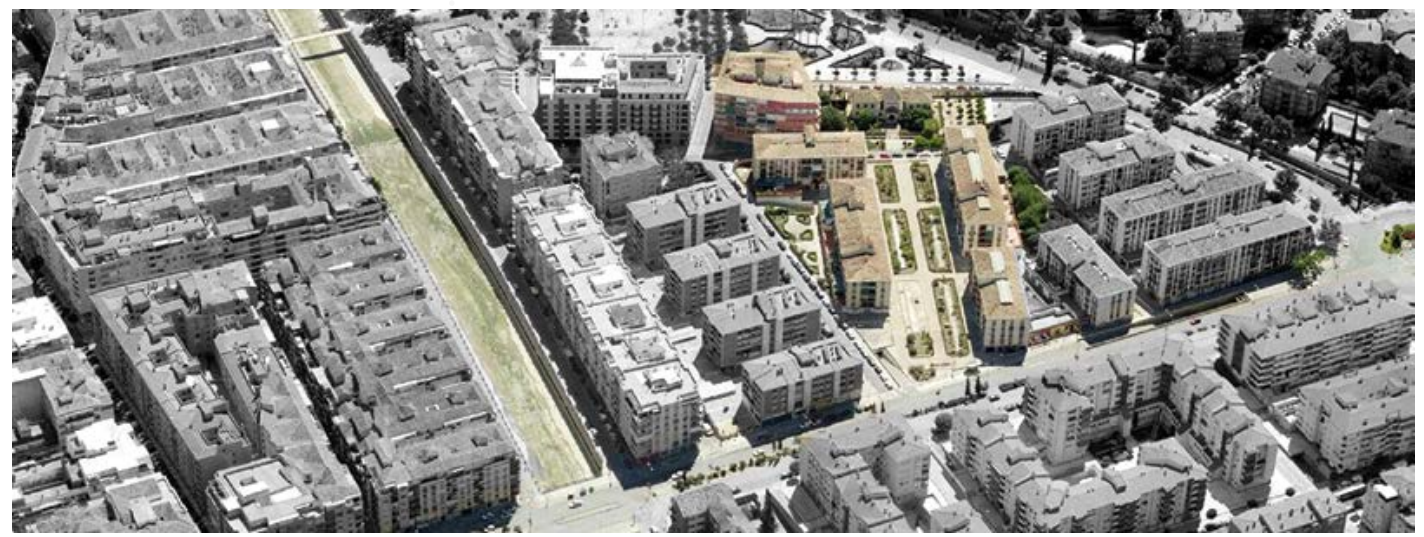

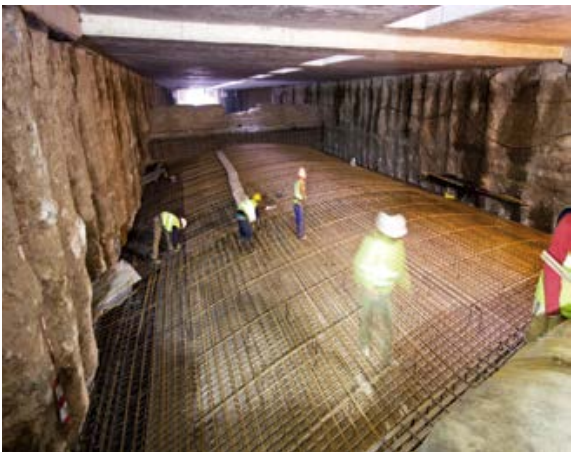

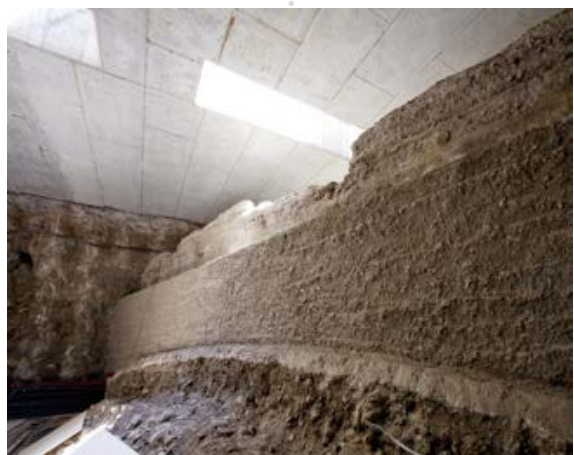

Figura 18. Sección transversal de la estación Alcázar Genil y proceso de apeo del albercón almohade. En la sección puede apreciarse la presencia de los restos almohades en una cota ligeramente superior al vestíbulo. Las dos imágenes siguientes ilustran la construcción de uno de los arcos escarzanos que apean el muro lateral del arbercón que se mantiene "in situ", la construcción de la bóveda de perfil escarzano que soporta el fondo de la alberca, y esta restituida de nuevo en su emplazamiento primitivo.

Fuente: Jiménez-Torrecillas et al. conjunto fue declarado Monumento del Patrimonio Histórico de España en 1922.

A finales del siglo XIX, Rafael Contreras añadió a ambos lados un cuerpo en dos alturas. La edificación se completa con un albercón a eje de la fachada de 128 x $27 \mathrm{~m}$ cuya capacidad le permitía controlar el regadío, trascendiendo lo estrictamente funcional para integrarse en el lugar y contribuir a la cualificación del paisaje. La solución no es extraña al mundo romano con el que la arquitectura

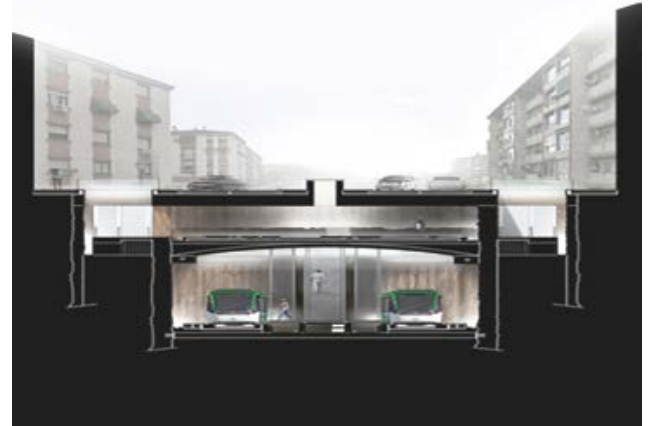

mentalmente en el período nazarí. Se conserva un pabellón central tipo qubba cubierto por una armadura de cuatro paños ataujerada de ruedas de lazo $\mathrm{y}$ dos alas laterales cerradas con alfarjes planos. El

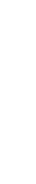

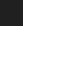



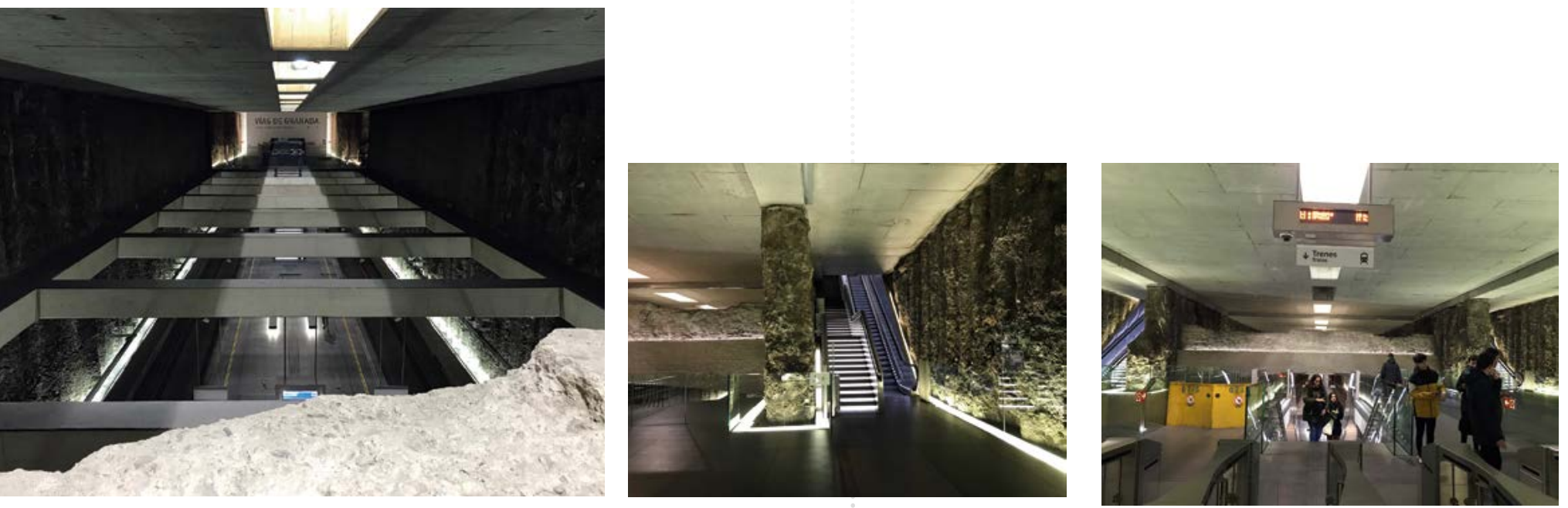

La construcción del metropolitano de Granada, con un tramo soterrado que atraviesa longitudinalmente el camino de Ronda, contempla la construcción de tres estaciones en este trazado destacando por su carácter emblemático la Estación Alcázar Genil.

La ejecución de esta presenta una mayor complejidad, ya que tiene que descender por debajo de la cota del río Genil. La obtención del vacío hasta alcanzar la profundidad deseada, se realiza mediante una empalizada de pilotes fabricados "in situ" sin camisa.

Posteriormente se procede al vaciado, construyendo la losa de cobertura que también sirve de entibo al muro de pilotes. Se repite el proceso con la extracción de tierras hasta salvar el primer nivel del vestíbulo realizando un segundo forjado, que se completa con una secuencia de vigas riostra para acodalar el muro de pilotes a media altura. Terminada la extracción de tierras se realiza la losa inferior que se entesta de nuevo a los pilotes y sobre la que descansan los andenes. El proyecto inicial

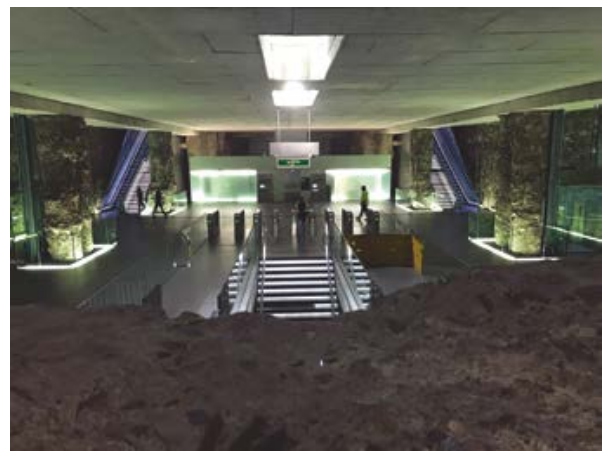

Figura 19. Estación Alcázar Genil.

Fuente: Bernardino Líndez-Vílchez.

contemplaba ocultar los pilotes con una piel metálica fijada sobre una lámina gruesa gunitada de hormigón.

En el proceso de excavación aparece el albercón de la almunia Alcázar Genil a una cota ligeramente superior al vestíbulo, coincidiendo con el tramo del camino de Ronda bajo el que se ocultaba, ya que el resto había sido destruido en la década de los años 70 del siglo pasado por las dos urbanizaciones colindantes para la construcción de sótanos de aparcamiento. 


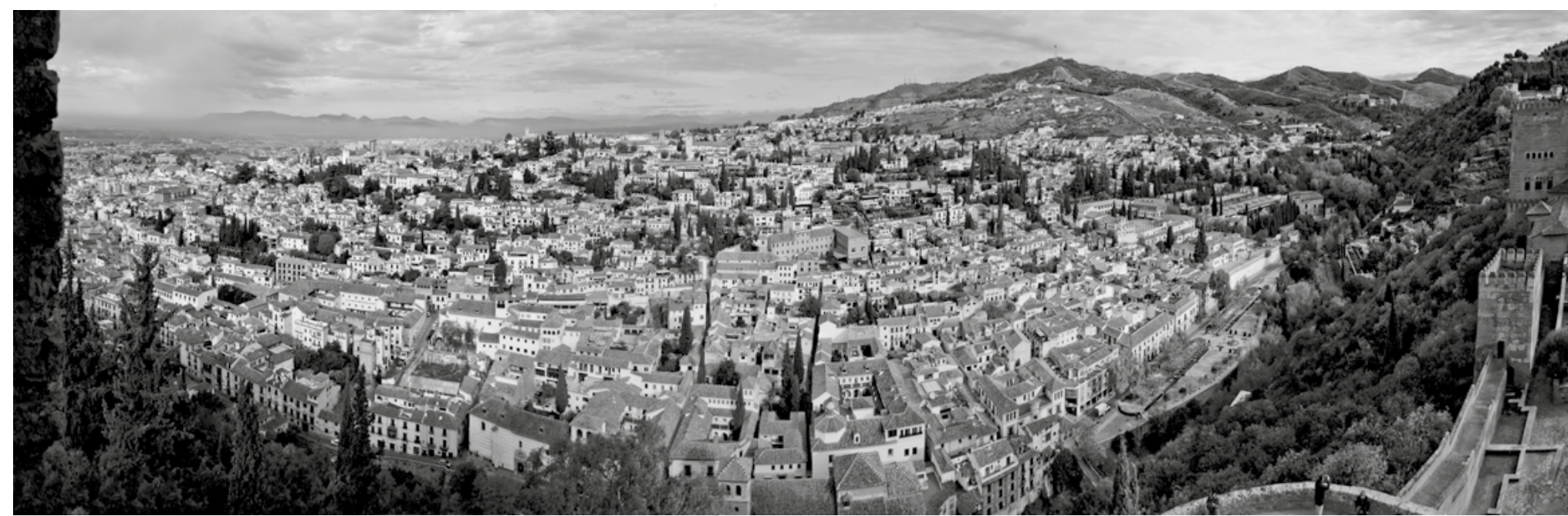

Figura 20. Vista panorámica del Albaicín desde la Torre del Homenaje en la Alhambra.

Fuente: Bernardino Líndez-Vilchez.

El hallazgo y la importancia de los restos arqueológicos encontrados aconseja la contratación de un arquitecto, encargo que recae en Antonio Jiménez Torrecillas. Éste se fija como objetivo principal salvar los artefactos arqueológicos, ponerlos en valor y facilitar la visita pública de los mismos. Con renovada pasión que transmite al resto de técnicos y obreros, adopta las primeras decisiones de proyecto. Los $18 \mathrm{~m}$ del albercón que han aparecido han de mantenerse tal cual se han encontrado. Los muros largos de la fábrica almohade se apean con un arco escarzano de hormigón armado vertido sobre el propio terreno que actúa como cimbra, manteniendo así la textura de éste después del vaciado.

E1 resto de la base de la alberca se desmonta y se acopia hasta completar la bóveda escarzana que resulta entre ambos arcos, utilizando de nuevo el terreno como cimbra, y apeando el organismo estructural resultante en la empalizada de pilotes la- terales. Finalizado éste, se procede a la reubicación de los restos arqueológicos en su lugar de origen, protegidos con un pavimento de vidrio transparente para facilitar la visita del público.

La decisión de conservar el tramo de alberca afecta a las escaleras y ascensor que sufren un ligero desplazamiento y a la superficie del vestíbulo que se reduce sin que altere su actitud funcional. Las paredes resultantes de la excavación muestran la honestidad constructiva y material de los pilotes en alternancia con el terreno natural, que se filtra entre estos, dibujando los estratos que conforman la historia. Paisaje cultural que a los ojos del arquitecto se convierte en documento cuya lectura facilita la comprensión del pasado reciente y que conecta a través de la arqueología con el legado de la ocupación musulmana en la ciudad.

La dialéctica que se establece entre pasado y presente como mecanismo de conexión con el futuro se convierte de nuevo en idea de proyecto. 
La áspera textura de los pilotes de hormigón, junto a la desnudez de los estratos que han ido conformando la historia, se fijan con resinas transparentes facilitando su lectura. La luz, que se filtra cenitalmente a intervalos ritmados, formaliza ante nuestros ojos el espacio. La cualidad del nuevo escenario arquitectónico trasciende lo estrictamente funcional para convertirse en museo, sala de exposiciones, pasarela de moda...

Se tiende el puente de conexión entre pasado y futuro a través del presente, concediendo idéntico valor a cada capítulo de la historia en una extraordinaria lección póstuma de arquitectura ${ }^{15 .}$

Me gusta pensar que hago arquitectura desde hace 6000 años, desde que existen pinturas al abrigo de las cuevas. Formar parte de un gremio u oficio, ser eslaboón de una cadena humana que, de muy distintas maneras, proponer confort y cobijo a los demás.

Me gusta ver el mundo como un piso de estudiantes que todos compartimos. En ese mundo hay compañeros de piso que llegaron antes que nosotros, que vivieron en la habitación que hoy es la nuestra. Un año alguien pintó. Al siguiente otro colocó una balda. En una ocasión encontré, sobre la mesa de mi nueva habitación vacía, una botella de vino y una nota. Mi desconocido amigo se había marchado ya. Otros nuevos, sin duda, llegarán.

15 "La capacidad sintética de su primera obra —y los ecos posteriores en otras viviendas, como la levantada en Benidorm o en "mi casita de la playa" que, entre pinos, había diseñado en Rota para su familia - ha convivido siempre en este excepcional arquitecto discreto con una huella artesanal en las rehabilitaciones. Moldeados a mano más que dibujados en el plano, los proyectos de restauración de este arquitecto respetuoso y visionario a la vez destilan afecto por su ciudad". (Zabalbeascoa, 2015, s.p.).
Herencia, evolución...: transmisión. El verdadero valor no está tanto en lo que generosamente hemos heredado, como en aquello que generosamente debemos aportar (Jiménez, 2016, p.106).

\section{En este contexto:}

Se superan los criterios de conservación y restauración del patrimonio aplicados hasta el momento, optando por los más modernos y totalizadores de gestión e intervención, a lo que habríamos de sumar las políticas sostenibles. Entiendo que sería necesaria también la inclusión de la noción de "huella ecológica" forzando su asimilación conceptual en la disciplina urbanística como el área necesaria de territorio a proteger para garantizar la sostenibilidad de los recursos paisajísticos y patrimoniales (Líndez, 2017, p. 27).

Territorio, ciudad y arquitectura en la conformación de un paisaje cultural que Antonio Jiménez Torrecillas ha sabido leer, desde una mirada contemporánea, sellando y tejiendo las distintas capas de la historia para rescatar y evidenciar su valor patrimonial. 
Campo, A. (enero, 2005). Fragmento de la entrevista realizada al arquitecto. Revista Volumenes (17).

Campo, A. (2005). El cielo sobre el cielo. Sobre el Centro José Guerrero en Granada de Antonio Jiménez Torrecillas. Revista Documentos de Arquitectura, (61).

Capitel, A. (1992). Metamorfosis de monumentos y teorías de la restauración. Madrid: Alianza.

Fernández, G. (2001/02). La Rehabilitación del Albaicín, Patrimonio de la Humanidad. Granada: Proyecto de la oficina de rehabilitación del Albaicín. Consejería de vivienda y ordenación del territorio.

González, C. (2001). Ciudad y poblamiento romano en la provincia de Granada durante el Alto Imperio. Habis, 32, 271-296.

Hernández, R. ( 17 de junio de 2015). Muere Jiménez Torrecillas, arquitecto apasionado y cabal. Diario Granada Hoy. Recuperado de https://www.granadahoy.com/ granada/Muere-Jimenez-Torrecillas-arquitecto-apasionado_0_926607426.html

Jiménez Torrecillas, A. (2006). El viaje de vuelta. El encuentro de la contemporaneidad a través de lo vernáculo [Tesis doctoral]. Universidad de Granada. Recuperada de http://hdl.handle.net/10481/1393

Jiménez Torrecillas, A., Hernández-Soriano, R., Ruiz, L.M.; Rodríguez-Aguilera, A., Tienza, C., Garzón, F., Carvajal, R., Sánchez-López, A. y Moreno, J. D. (2014). Integración de restos arqueológicos Almohades en el metropolitano de Granada. La investigación multidisciplinar para el proyecto y desarrollo de infraestructuras contemporáneas en los centros históricos. Informes de la Construcción, 66(535): e036, doi: http://dx.doi.org/10.3989/ic.13.023.

Jose M. Gómez y Daniel López (eds.) (21 septiembre de 2016). Antonio Jimenez Torrecillas. Márgenes Arquitectura 10. Recuperado de https://issuu.com/margenesarquitectura/docs/margenesarquitectura10_ajt_preview
Koolhas, R. (2006). La ciudad Genérica. Barcelona: Gustavo Gili.

Líndez, B. (2014). Tetuán, herencia viva. Granada: Editorial Universidad de Granada.

Líndez, B. y Jiménez, A. (abril, 2017). Granada. E1 lastre de la historia, pasado y presente. Mouseion, Canoas, (26), 11-31. Recuperado de http://dx.doi.org/10.18316/mouseion.v0i26.3612.

Líndez, B. y Rodríguez, M. (2015). La bóveda anular del Palacio de Carlos V en Granada. Hipótesis constructiva. Informes de la Construcción, 67(540): e125, doi: http://dx. doi.org/10.3989/ic.15.004.

López, R. (1987). Tradición y Clasicismo en la Granada del XVI. Arquitectura Civil y Urbanismo. Granada: Diputación Provincial.

Navarro, J. y Jiménez, P. (1995). Casas y palacios de Al-Andalus. En J. Navarro (Ed.), Casas y palacios de Al-Andalus. Siglos XII-XIII (pp. 17-32). Granada: Fundación El legado Andalusí, Junta de Andalucía.

Orihuela, A. (1996). Casas y Palacios Nazaries. Siglos XI$I I-X V$. Barcelona: Fundación El legado Andalusí, Junta de Andalucía, Lunwerg Editores.

Orihuela, A. y Almagro, A. (1996). Arquitectura en Al-Andalus. Jardín con plantas y alzados de papel. Granada: Fundación El legado Andalusí, Junta de Andalucía.

Puerta-Vílchez, J.M. (2007). La Alhambra y el Generalife de Granada.Artigrama, 22, 197.

Zabalbeascoa, A. (21 de junio de 2015).Fallece Antonio Jimenez Torrecillas, arquitecto vanguardista. El País. Recuperado de https://elpais.com/tag/fecha/20150621 


\section{CONTENIDO}

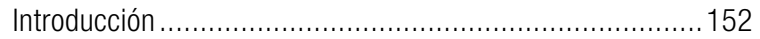

Consideraciones teóricas ............................................... 153

Las estrategias de renovación, rehabilitación y

redesarrollo urbano en el contexto de la globalización ........ 157

Las estrategias de renovación y rehabilitación urbana

en Buenos Aires 1996-2016

Marco jurídico-administrativo .......................................158

Las políticas urbanísticas y de desarrollo

económico-territorial ......................................................161

Gestión 1989-1995 …..................................................161

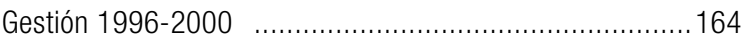

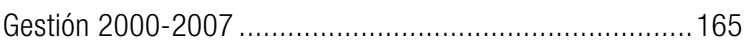

Gestión 2007-2011 y 2011-2015 ....................................166

Gestión 2015 (en curso) ............................................... 168

Reflexiones finales ................................................. 169

Referencias........................................................ 170

Mignaqui, I. y Ciccolella, P. (2019). Políticas de renovación, rehabilitación y desarrollo urbano en Buenos Aires. Una revisión crítica. En Yory, C. M. (Ed.), Renovación urbana. Globalización y patrimonio (pp. 151-173). doi: $10.14718 / 9789585456624.2019 .8$

1 Profesora e investigadora en la Facultad de Arquitectura, Diseño y Urbanismo de la Universidad de Buenos Aires (FADU - UBA). Directora del Programa Urbanismo y Ciudad, Facultad de Arquitectura, Diseño y Urbanismo de la Universidad de Buenos Aires.

2 Profesor titular del Departamento de Geografía de la Universidad de Buenos Aires. Director del Programa de Estudios sobre Desarrollo Territorial y Estudios Metropolitanos, Instituto de Geografía, Universidad de Buenos Aires. Director de la Maestría en Políticas Ambientales y Territorial de la Facultad de Filosofía y Letras, Universidad de Buenos Aires. Miembro Comité Científico de la RIGPAC. 